\title{
LXXII. On the possibility of alloying iron with manganese
}

\section{David Mushet Esq.}

To cite this article: David Mushet Esq. (1816) LXXII. On the possibility of alloying iron with manganese, Philosophical Magazine Series 1, 48:223, 354-360, DOI: 10.1080/14786441608637684

To link to this article: http://dx.doi.org/10.1080/14786441608637684

里 Published online: 27 Jul 2009.

Submit your article to this journal

Џ Article views: 2

Q View related articles $\asymp$ 
flected back again to the optic nerve to produce vision, or sent sation, as nothing but nerves is sensible.

It appears to me, then, that Mr. Horn's theory demands two reflections which are neither proved, nor necessary, nor consistent with the nature of transparent fluids; and therefore I feel inclined to retain my old opinion, that light acts upon the optic nerve and excites sensation.

I know the difficulty of getting rid of notions which have become habitual, and therefore I suppose my want of conversion is owing to my having long thought as I do, and to Mr. Horn's reasons and reflections not being sufficiently caustic to reach $m y$ case, and produce in me a new and juster way of thinking: at the same time I by no means expect that my opinions will produce any change in $\mathrm{Mr}$. Horn's ideas: however, there can be no harm in diversity of opinions on doubtful subjects, if goodhumour be president. I am, sir,

Skiff-haven, Nov. 1, 1616.

Your most obedient servant,

W. Pater.

LXXII. On the Possibility of alloying Iron with Manganese. By David Mushet, Esq. of Coleford, Forest of Dean*. To HAve in your last number shown the difficulty of combining, to any material extent, metallic manganese with cast iron, by fusing the latter with the black oxide of manganese and certain proportions of charcoal. I next attempted to form the alloy of the two metals by fusing certain proportions of the ore of each metal in mixture, cousidering that results obtained under such a mode of operation, would indicate the practicability of working, if nevessary or advantageous, ores of manganese along with the ordinary ores of iron smelted in our blast furnaces, either for the production of good bar iron or steel.

I selected a large piece of argillaceous iron ore, which I prepared by roasting and subsequent pulverization; I then passed it through a small wire sieve: the oxide of manganese and charcoal were prepared in a similar way, and the whole kept shut up from access to atmospheric air, to prevent as much as possible any irregularity in the results by the absorption of moisture. The crucibles and lids were accurately ground and fitted to each other, and entrely free (by being previously baked) of any coaly or extraneous matter.

No. 1. Fused of the argillaceous iron ore $\quad$. 500 grs. charcoal $1-5 \mathrm{th}$, or .. $\quad . .100$

A crystallized metallic button was the result of this fusion,

* Communicated by the Authog. 
weighing 223 grains, or $44 \frac{3}{4}$ per cent.; the earthy matter of the ore had resolved itself into a brownish opaque glass, partially transparent in thin fragments.

No. 2. Argillaceous iron ore .. .. .. 500 grs.

Oxide of manganese . . $\quad \ldots \quad \ldots 100$

Charcoal $\quad \ldots \quad \ldots \quad \ldots \quad \ldots \quad \ldots 100$

Result of the fusion of this mixture, a rough irregularly crystallized button of metal, weighing 217 grains, which is a produce of $43 \frac{4}{10}$ per cent. Glass opaque blackish brown without any transparency.

No. 3. Argillaceous iron ore .. ... .. 500 grs.

Oxide of manganese from which 22 per cent. of oxygen and moisture had heen

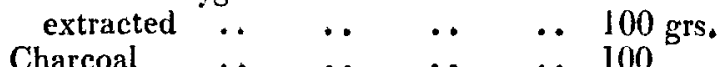

Result-A smooth regularly crystallized metallic button, weighing 230 grains, equal to 46 per cent. On a comparative examination of the fractures of these experiments, the following remarks were made.

No. 1 button possessed a clear metallic fracture inclining to steel, filed and cut soft, and possessed considerable tenacity. The grain was flat, confused like steel approaching to cast-iron. No. 2 broke with a dark gray blue glance, more perfectly granular than the former, cut softer at first, but possessed less real tenacity. No. 3 was extremely brittle, and disparted on the first application of the chisel:-fracture different from the former, silvery grav, crystalline distinct small grain, and resembled on the whole some, varieties of gray cast-iron. This difference of appearance and increase of weight mav probably with justice be attributed to a small portion of metallic manganese being reduced from the roasted oxide. The glass of the first button was cloudy opaque, though in thin fragments transparent. That of the second button entirely opaque : but the glass of the third button with the de-oxidated manganese was amber green, thoroughly transparent in thin pieces.

The following experiments were performed with an enlarged dose of charcoal, to compare results with the former.

No. 4. Argillacenus iron ore .. .. .. 500 grs. Charcoal $\frac{1}{4}$ th $\quad \ldots \quad \ldots \quad \ldots \quad \ldots \quad \ldots \quad 125$

The fusion of this mixture yielded a perfect crystallized button of iron weighing 257 rrains, equal to $51 \frac{1}{4}$ per cent. Glass lead-milky-blue, veined : eight grains of charcoal mixed with some brilliant specks of carburet of iron were found unacted upon. This fusion was so perfect, and the metallic reduction so entire, that there did not seem to remain in the glass any appreciable cuantity of iron. The addition of 25 grains of char- 
coal in this experiment beyond that in No. 1 , revived 34 grains of additional produce, and in every respect effected a complete reduction of the ore.

No: 5. Argillaceons iron ore .. $\quad . . \quad \ldots 500$ grs.

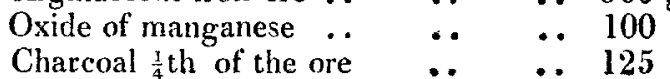

A rough metallic button resulted from the fusion of this mixture, which with some small globules weighed 245 grains, equal to 49 per cent. Glass grass green considerably transparent :four grains of charcoal remained unacted upon.

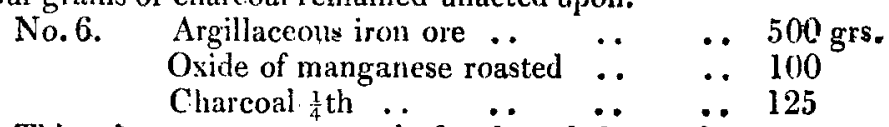

This mixture was accurately fused, and the result was a perfect metallic button weighing 246 grains, which is equal to 49,20 per cent. Glass light green but clouded, transparent in thir pieces; not so bright as No.5, but more transparent than No. 4 . The same quantity of charcoal remained over in this as in the last experiment. From the three immediately preceding fusions with an excess of charcoal, it cannot be decidedly inferred that the increased produce beyond that of No. $i, 2,3$, was derived from the manganese; the reverse of this conclusion rather appears on the face of the experiments, seeing more metal was obtained without manganese than with it, in the proportion of 257 to 245 and 246 . Lest any error should have taken place in the weighing of No. 4, which yielded 257 grains of iron, this experiment was twice repeated, and the results were 240 and 244, making an average of $245 \frac{3}{3}$,-Average of the fusions of No. 5 and 6 with manganese ... .. $245 \frac{1}{2}$.

On the whole, it appears doubtful whether in these experiments there was any real alloy of manganese with iron; the sofitary increase of weight in No. 3 and its peculiar fracture being the only circumstance in favour of this conjecture. On dividing and comparing the fractures of the metallic buttons, No. 4, 7, and 8 (the same experiment) were exactly alike. In these no manganese was used; the quality was white cast-iron, with a blueish glance, and a grain indicative of an approach to steel. No. 1 and 2 evidently belonged to the class of steels, so far as a commencement of grain was visible ; but in respect to ductility or softuess they were still closely allied to the hardest sorts of cast-iron : the former had experienced an excess of carbon, the latter had absorbed all that was presented to them in mixture. No. 5 and No. 6 were much alike, and similar to No. 3 , in which de-oxidated manganese was used. The fractures were of a darker glance than $4,7,8$, minutely but regularly granulated and crystallized. It appeared, therefore, that 
the addition of oxide of manganese to the amount of 1-5th the weight of the iron ore, alters the grain and fracture of castiron, where a sufficient quantity of charcoal is present to effect a perfect reduction of it, though it does not appear to add to, or impair to any observable amount, the quantity of metallic produce.

No. 9. Argillaceous iron ore .. $\quad$.. $\quad$.. 500 grs.

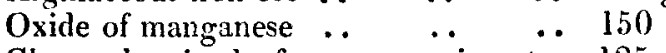

Charcoal as in the former experiments 125

The result of this fusion was a crystallized radiated button weighing 247 grains, $49_{\frac{4}{50}}$ per cent. Glass lightt blueish green, with considerable transparency. As part of it had escaped, the experiment was repeated, and an elegant prismatic crystallized metallic button again obtained, weighing 247 grains, which proved beyond any doubt the accuracy of the result.

No. 10 .

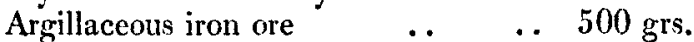

$$
\begin{aligned}
& \text { Oxide of mangainese .. } \quad . . \quad \text {.. } 150
\end{aligned}
$$

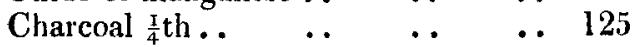

Result from this fusion a crystallized button of metal weighing 240 grains, 48 per cent. Glass light-coloured flinty brown, with a good deal of transparency. Ten grains of metallic carburet were found unreduced; some globules of metal put on a smooth shining surface resembling iron highly charged with carbon.

No. 11. Argillaceous iron ore $\quad$.. $\quad$.. $500 \mathrm{grs}$. Manganese roasted $\quad . \quad$.. $\quad$. 250

Charcoal $\frac{1}{4}$ th, or $\quad$.. $\quad$.. $\quad . .125$

Result-A crystallized button and some carburetted globules weighing 253 grains, equal to $50_{T}^{6}$ per cent. It was in this experiment, for the first time, noticed that some of the globules were not attracted by the magnet, and this peculiarity was attributed to a high alloy of metallic manganese with iron: the glass was of a lead-gray colour, transparent in thin fragments: nine grains of magnetic earburet of iron were found unreduced.

No. 12. Argillaceous iron ore.. $\quad$.. $\quad$.. $500 \mathrm{grs}$. Manganese roasted $\quad . . \quad \ldots \quad \ldots \quad \ldots 300$

$\begin{array}{llllll}\text { Charcoal } & \ldots & \ldots & \ldots & \ldots & 125\end{array}$

The metallic button resulting from this fusion was accurately crystallized, and attracted by the magnet; there were, however, nearly twenty globules with smooth carburetted surfaces that were but slightly affected by the magnet. The whole produce weighed 260 grains, equal to 52 per cent. The glass was finty clouded, but possessed a good deal of watery transparency.

No. 13.

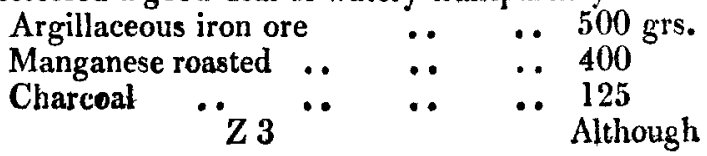


Although the fusion of this mixture was most perfect, yet the diminished produce and colour of the glass indicated an excess of ores to charcoal. The metallic button weighed 243 grains, or $48 \frac{6}{10}$ per cent. The quantity of resulting glass more than half filled the crucible; the colour dark grass green, transparent in thin fragments.

No. 14. Argillaceous iron ore $\quad . . \quad \ldots 250 \mathrm{grs}$.

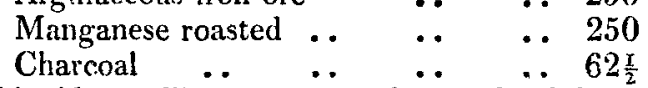

A smooth skinn'd metallic button was the result of the fusion of this compound, weighing 112 grains, or $44 \frac{8}{T_{0}}$ per cent.; so that an increased demetallization of 4 per cent. had taken place, in consequence of increasing the proportion of manganese, beyond that of the last experiment.-The colour of the glass now obtained was dark green inclining to amber. From the result of these experiments it is evident that the alloy of manganese had reached its maximum in experiment 12 , where a metallic return was obtained of

$$
\text { .. } \quad \ldots \quad \text {. } 260
$$

Average produce of three fusions of the iron

$$
\begin{array}{llllll}
\text { ore per se } & \text {. } & \text {. } & \text {. } & \text {.. } & 245 \frac{1}{2}
\end{array}
$$

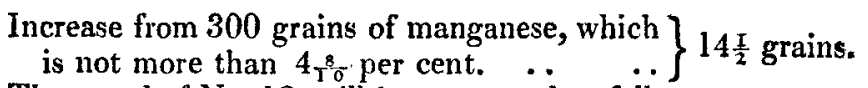

The metal of No. 12 will be composed as follows:

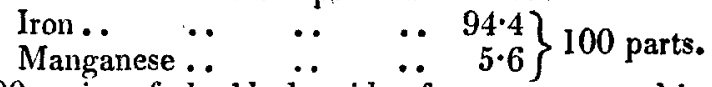

No. 15. 200 grains of the black oxide of manganese used in these experiments were fused per se, and a perfect glass formed of a ruby wine colour, though not possessed of much transparency.

No. 16. 200 grains of deoxidated manganese were fused in a similar manner, and a glass similar to the last obtained.

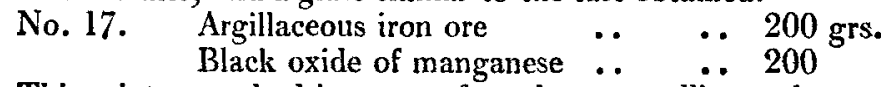

This mixture melted into a perfect glass, metallic, and possessed of a lustre resembling that of a highly-polished razorblade.

The three following experiments were made to ascertain the comparative demetallization of the oxide of manganese with a given quantity of charcoal, to exhibit the probable effects that might be produced on the burden of the blast-furnace in the event of ores of manganese being smelted along with our iron ores.

No. 18. Argillaceous iron ore.. .. $\quad . .500 \mathrm{grs}$.

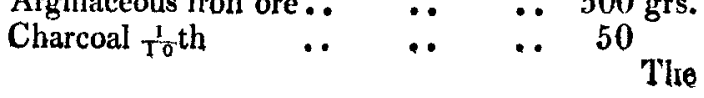


The result of this fusion was a smooth button of soft iron weighing 126 grains, equal to $25 \frac{8}{10}$ per cent. Glass opaque, shining, and highly metallic.

No.19. Argillaceous iron ore $\quad$.. $\quad$.. 500 grs.

$\begin{array}{llllll}\text { Charcoal } & \text {. } & \text {. } & \ldots & \ldots & 50\end{array}$

Oxide of manganese ... $\quad \ldots \quad \ldots 200$

Result of this fusion a metallic button weighing 55 graine, which is only equal to 11 per cent. being a diminution of $7 l$ grains of iron, or upwards of 14 per cent., in consequence of the addition of 200 grains of manganese. Glass black, shining, metallic, opaque.

No. 20. Argillaceous iron ore $\quad$.. $\quad . .500$ grs.

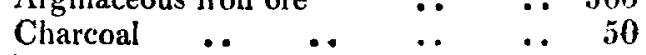

Manganese roasted $\quad \ldots \quad \ldots \quad \ldots 200$

The metallic button resulting from this fusion weighed 60 grains, or 12 per cent. The demetallization therefore occasioned by roasted manganese is less by 2 per cent. than when raw ore is used : this is of course occasioned by part of the oxygen of the ore being expelled from it in roasting, leaving so much less to act upon the charcoal of the experiment; the extent of the decarbonation in both being measured by the lack of metallic produce when the manganese was employed. In No. 19 a metallic deficiency was experienced of 71 grains, a quantity which required for its reduction 28 grains of charcoal : and in No. 20, a loss of 66 grains of iron, which would have, according to the result of No.18, required 18 grains of charcoal.

From these facts it appears to me extremely probable that, should the ores of manganese ever be introduced into the smelting furnace, a considerable diminution of the carbonating properties of the coke will be felt; or, in other words, less burden will be carried, and more coke necessary to supply the waste occasioned by the combination of the oxygen of the manganese with the fuel. Experiment and practice alone will determine the comparative advantages and disadvantages that may resulc from so novel a proceeding, if ever introduced at our ironworks.

In most ores of manganese there is a portion of moisture and oxygen that may be expelled at a low heat; but the greatest quantity of the latter remains combined with the metal, and from which the last portions are not easily expelled even in the highest temperature of the essay furnace.

The essayist, not having the same means to guide him in fixing the perfection of his art on the development of a transparent glass (as is, or ought to be, the case in operating with ores of iron) is frequently left in the dark, and puzzled to deternine whether he has obtained the whole metallic produce from the 
ore which is the subject of his experiments. Ores containing 30 per cent. and upwards of manganese, as in experiments 15 and 16, will fuse per se into glasses that will transmit light, and in thin fragments exhibit perfect transparency. This is not at all the case with ores of iron; a retention of 5 per cent. of iron will give an opaque bottle-green glass, and when it amounts to 10 per cent. the glass becomes black, shining, and metallic.

Recapitulation of the foregoing Experiments as to metallic Produce.

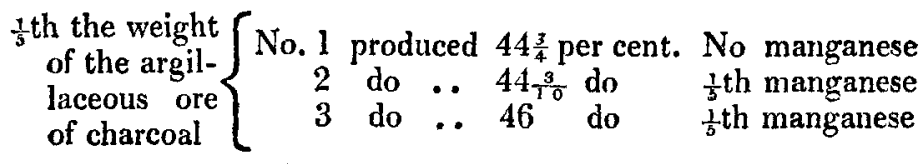

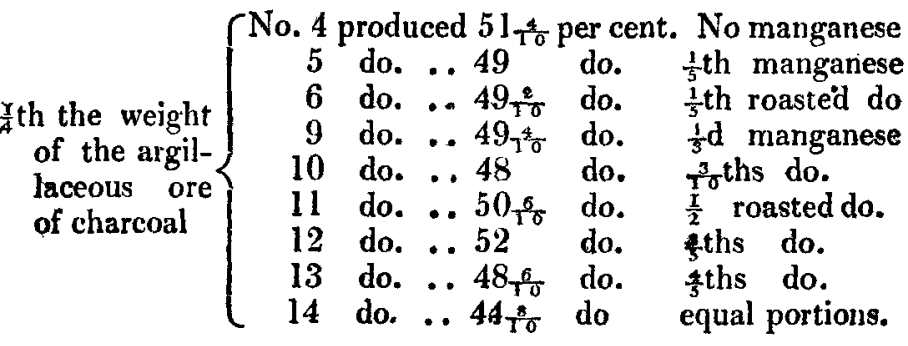

LXXIII. On Flame. By J. Murray, Esq.

To Mr. Tilloch.

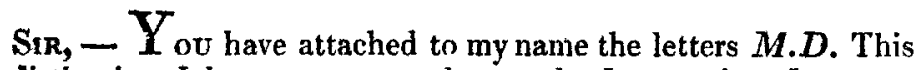
distinction I have not assumed, nor do I covet it. I request you will ectify the error, lest my more humble efforts in the cause of truth and science might in some instances, by my imperfect details, detract from the superior merits of Dr. John Murray of Edinburgh*. By a typographical error unhallowed is printed " hallowed."

In some instances, by introducing into the flame of a candle a spatula of ivory with gunpowder, I have withdrawn it in a moist state; and from the circumstance that fulminating silver inserted into the cone of flame has not been exploded for some seconds, - I deem it probable that the interior is filled up with aqueous matter, which emanates from the interior surface of the flame, as well as exterior. This medium of aqueous particles

- Identity of name led us into the mistake alluded to, and must plead our excuse,-EDrT. 